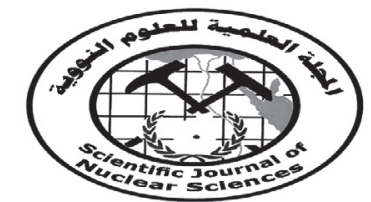

Nuclear Materials Authority

P.0.Box 530 Maadi, Cairo, Egypt
ISSN 2314-5609

Nuclear Sciences Scientific Journal vol. 1 , p $167-170$

2012

\title{
IMPROVEMENT OF LOW-GRADE SILICA SAND DEPOSITS IN UM BOGMA AREA-WEST CENTRAL SINAI, EGYPT
}

\author{
IBTEHAL F. ABDEL-RAHMAN and ASHRAF A. ELSHENNAWY ${ }^{1}$ \\ Faculty of Science, Suez Canal University; Nuclear Materials Authority ${ }^{l}$
}

\section{ABSTRACT}

There are several silica sand deposits in Sinai, but they require upgrading to provide a raw materials acceptable for the glass manufacture. This study records beneficiation of low-grade silica sand deposits near Um Bogma at west central Sinai. The improvement techniques of ore dressing involving wet sieving, attrition scrubbing, decantation, gravimetric and magnetic separations have been applied depending on the physical properties of the constituents.

\section{INTRODUCTION}

Sinai is endowed with enormous resources of white silica sand which is the main ingredient of glass manufactures. Some of these white sands are contaminated by iron oxides and other metallic elements that do not meet the basic chemical specifications for industrial utilization, namely for glass production. These low grade white sands require upgrading by various combinations of mineral processing techniques to provide silica sand of high quality and great abundance acceptable for glass industry.

Some of these deposits of silica sand occur within Abu Thora Formation representng the Upper Sandstone Series of the Carboniferous age (Abu-Shabana, 1998 and Kora, 1984). The present study reports improvement of these deposits through mineral processing techniques of physical concentration; these were: wet sieving, scrubbing, decantation, shaking table and magnetic separation. A representative sample of $50 \mathrm{Kegs}$ of the sand were used in the present study, and was directed as follows: 30 Kegs were directed to the upgrading processes, 6 samples $100 \mathrm{~g}$ each were used for screen analyses (Table 1) and the remaining (29.4 Kegs) were stored as a reference sample.

Table 1: result of screen analyses of bulk samples

\begin{tabular}{l|r|r|r|r|r|r}
\hline Sample no./mm sieve & $\mathbf{1}$ & $\mathbf{2}$ & $\mathbf{3}$ & $\mathbf{4}$ & $\mathbf{5}$ & $\mathbf{6}$ \\
\hline Over $2.00 \mathrm{~mm}$ & Nil & Nil & Nil & Nil & Nil & Nil \\
\hline $2-1 \mathrm{~mm}$ & Nil & 0.008 & 0.006 & 0.01 & 0.018 & Nil \\
\hline $1-0.5 \mathrm{~mm}$ & 0.18 & 0.16 & 0.14 & 0.18 & 0.16 & 0.2 \\
\hline $0.5-0.25 \mathrm{~mm}$ & 44.92 & 45.22 & 41.98 & 43.98 & 44.96 & 45.01 \\
\hline $0.25-0.125 \mathrm{~mm}$ & 45.32 & 46.68 & 48.88 & 47.22 & 46.62 & 47.42 \\
\hline $0.125-0.063 \mathrm{~mm}$ & 9.28 & 7.93 & 8.92 & 8.50 & 8.24 & 7.32 \\
\hline
\end{tabular}

\section{METHODS}

The following methods were applied in the present study:

\section{Wet Sieve Analyses}

A wet sieving process was set up as a dry process, i.e. the sieve stake is clamped onto the sieve shaker. The sample is placed on the top sieve $(0.063 \mathrm{~mm})$ and supplemented by a water-spray nozzle. The rinsing is carried out until the sample residues on the sieve are clear from slimes. 


\section{Attrition Scrubbing}

An attrition cell was used for mechanically eliminating impurities stuck on the surfaces of the sand particles. This attrition cell is a horizontal cylindrical attritor fitted with a specially designed mechanical movement. The sample was poured in the scrubbing cell with enough water to produce thick slurry having $75-80 \%$ solids. The scrubbing cell was operated for 20 minutes at $980 \mathrm{rpm}$. After the completion of the set time, the total charge was taken out and the sand was separated from the slurry by decantation.

\section{Decantation}

In this operation, the sample was stirred by a mechanical stirrer. Then decant the water with the suspended slimes. The operation is repeated several times until we decant almost all the slimes and get the material.

\section{Gravimetric Separation}

The gravimetric separation depends on the difference of specific gravity between the important minerals and the gangue. This was achieved by using the "shaking table concentrator". The prepared pulp (solid + water) was transferred to the table. Feeding was continued until the solids distribution on the table attained, approximately, a steady state. The collected materials were dried and subjected to concentration by magnetic separation.

\section{Magnetic Separation}

A further concentration was conducted by dry magnetic separation using the "Induced Roll Separator".

\section{RESULTS}

\section{Screen Analysis}

The results of the screen analyses of bulk samples are presented in Table 1. The average result of all the samples shows that the silica sands are well sorted; more than $75 \%$ of the grains are with grain size of 0.125 to $1.00 \mathrm{~mm}$, coarse to fine sand range. More than $40 \%$ of the grain size is within 0.25 to $1.00 \mathrm{~mm}$,i.e. medium to coarse sand range (Table 2).

Concentration of Jabal Allouga Silica Sand

Initially chemical analysis was done on the bulk samples by XRF technique. The results of the chemical composition of 6 bulk samples are given in Table 2. It shows that $\mathrm{SiO}_{2}$ ranges from $85.15 \%$ to $86.13 \%$ representing the most abundant oxide in the studied samples.

Chemical compositions on the products of wet sieving for the same samples show a slight improvement of $\mathrm{SiO}_{2}$ up to 88.67 and do not intensively reduce the undesirable impurities compared to raw bulk samples. The results are given in Table 3.

Scrubbing and decantation the sample upgraded silica content to $93.12 \%$ and reduces iron content to $1.54 \%$ which are comparable with the bulk concentrate. Other oxides content such as $\mathrm{Al}_{2} \mathrm{O}_{3}, \mathrm{CaO}, \mathrm{MgO}, \mathrm{Na}_{2} \mathrm{O}, \mathrm{K}_{2} \mathrm{O}$ and $\mathrm{P}_{2} \mathrm{O}_{5}$ remained high, which are undesirable for glass industry. However, the silica content is still below the required level and the iron value is more than the specified value (Table 4).

Table 2: Chemical analysis data of raw bulk samples

\begin{tabular}{l|r|r|r|r|r|r}
\hline & $\mathbf{1}$ & $\mathbf{2}$ & $\mathbf{3}$ & $\mathbf{4}$ & $\mathbf{5}$ & $\mathbf{6}$ \\
\hline $\mathrm{SiO}_{2}$ & 85.36 & 85.15 & 86.13 & 85.48 & 85.25 & 85.41 \\
\hline $\mathrm{Al}_{2} \mathrm{O}_{3}$ & 7.80 & 7.77 & 7.35 & 7.69 & 7.78 & 7.84 \\
\hline $\mathrm{TiO}_{2}$ & 0.13 & 0.14 & 0.13 & 0.13 & 0.19 & 0.18 \\
\hline $\mathrm{Fe}_{2} \mathrm{O}_{3}$ & 3.99 & 4.59 & 3.69 & 3.79 & 3.99 & 4.01 \\
\hline $\mathrm{CaO}$ & 1.12 & 1.12 & 1.34 & 1.12 & 1.62 & 1.17 \\
\hline $\mathrm{MgO}$ & 0.4 & 0.2 & 0.2 & 0.4 & 0.2 & 0.4 \\
\hline $\mathrm{Na}_{2} \mathrm{O}$ & 0.25 & 0.33 & 0.33 & 0.33 & 0.33 & 0.33 \\
\hline $\mathrm{K}_{2} \mathrm{O}$ & 0.05 & 0.05 & 0.05 & 0.05 & 0.05 & 0.05 \\
\hline $\mathrm{P}_{2} \mathrm{O}_{5}$ & 0.05 & 0.06 & 0.05 & 0.05 & 0.06 & 0.04 \\
\hline $110 \mathrm{C}^{\circ}$ & 0.04 & 0.03 & 0.05 & 0.04 & 0.03 & 0.05 \\
\hline $550 \mathrm{C}^{\circ}$ & 0.53 & 0.43 & 0.46 & 0.35 & 0.36 & 0.33 \\
\hline $1000 \mathrm{C}^{\circ}$ & 0.26 & 0.09 & 0.14 & 0.36 & 0.10 & 0.14 \\
\hline $\mathrm{Total}^{\circ}$ & 99.98 & 99.96 & 99.92 & 99.76 & 99.96 & 99.95 \\
\hline
\end{tabular}


Table 3: Results of wet sieving concentration

\begin{tabular}{c|r|r|r|r|r|r}
\hline \multicolumn{1}{c|}{ Sample no. } & $\mathbf{1}$ & $\mathbf{2}$ & $\mathbf{3}$ & $\mathbf{4}$ & $\mathbf{5}$ & $\mathbf{6}$ \\
\hline $\mathrm{SiO}_{2}$ & 87.88 & 88.66 & 88.67 & 88.00 & 87.76 & 87.98 \\
\hline $\mathrm{Al}_{2} \mathrm{O}_{3}$ & 2.74 & 2.74 & 2.70 & 2.73 & 2.74 & 2.74 \\
\hline $\mathrm{TiO}_{2}$ & 0.09 & 0.10 & 0.09 & 0.09 & 0.12 & 0.21 \\
\hline $\mathrm{Fe}_{2} \mathrm{O}_{3}$ & 2.88 & 3.15 & 2.94 & 2.96 & 3.00 & 3.04 \\
\hline $\mathrm{CaO}$ & 1.14 & 1.14 & 1.36 & 1.14 & 1.65 & 1.19 \\
\hline $\mathrm{MgO}$ & 0.39 & 0.45 & 0.46 & 0.35 & 0.45 & 0.41 \\
\hline $\mathrm{Na}{ }_{2} \mathrm{O}$ & 0.57 & 0.66 & 0.66 & 0.53 & 0.66 & 0.66 \\
\hline $\mathrm{K}_{2} \mathrm{O}$ & 0.12 & 0.12 & 0.12 & 0.12 & 0.12 & 0.12 \\
\hline $\mathrm{P}_{2} \mathrm{O}_{5}$ & 0.04 & 0.04 & 0.04 & 0.04 & 0.04 & 0.04 \\
\hline $\mathrm{L} . \mathrm{O} . \mathrm{I} . \%$ & 0.35 & 0.29 & 0.39 & 0.35 & 0.30 & 0.39 \\
\hline
\end{tabular}

Table 4: Chemical analysis of attrited silica sands.

\begin{tabular}{l|r|r|r|r|r|r|r|r|r}
\hline Constituents & $\mathrm{SiO}_{2}$ & $\mathrm{Al}_{2} \mathrm{O}_{3}$ & $\mathrm{TiO}_{2}$ & $\mathrm{Fe}_{2} \mathrm{O}_{3}$ & $\mathrm{CaO}$ & $\mathrm{MgO}$ & $\mathrm{Na}_{2} \mathrm{O}$ & $\mathrm{K}_{2} \mathrm{O}$ & $\mathrm{P}_{2} \mathrm{O}_{5}$ \\
\hline Concentrate & 93.12 & 0.99 & 0.70 & 1.54 & 0.05 & 0.09 & 0.06 & $\mathrm{t}$ & $\mathrm{t}$ \\
\hline
\end{tabular}

The samples of Jabal Allouga silica sand were then concentrated by means of shaking table using different inclinations and flow rates. The best results are presented in Table 4. These results indicate that using the shaking table technique improves the silica content from $93.12 \%$ to $96.30 \%$ and reduces the iron content to $0.96 \%$. However, the result was still lower than the corresponding result obtained using scrubbing and decantation techniques.
The concentrate of gravimetric separation (shaking table) was also subjected to magnetic separation, using an induced roll separator. The results are shown in Table 6. A comparison of Table 5 and Table 6 indicates that magnetic separation improved the concentrate of shaking table from $96.30 \%$ to $98.90 \%$ for $\mathrm{SiO}_{2}$ and reduces iron from $0.96 \%$ to $0.05 \%$.

Table 5: Concentration by shaking table of Jabal Allouga silica sand.

\begin{tabular}{l|r|r|r|r|r|r|r|r|r}
\hline Constituents & $\mathrm{SiO}_{2}$ & $\mathrm{Al}_{2} \mathrm{O}_{3}$ & $\mathrm{TiO}_{2}$ & $\mathrm{Fe}_{2} \mathrm{O}_{3}$ & $\mathrm{CaO}$ & $\mathrm{MgO}$ & $\mathrm{Na}_{2} \mathrm{O}$ & $\mathrm{K}_{2} \mathrm{O}$ & $\mathrm{P}_{2} \mathrm{O}_{5}$ \\
\hline Concentrate & 96.30 & 0.53 & 0.10 & 0.96 & 0.03 & 0.05 & 0.06 & $\mathrm{t}$ & $\mathrm{t}$ \\
\hline
\end{tabular}

Table 6: Results of magnetic separation.

\begin{tabular}{l|r|r|r|r|r|r|r|r|r}
\hline Constituents & $\mathrm{SiO}_{2}$ & $\mathrm{Al}_{2} \mathrm{O}_{3}$ & $\mathrm{TiO}_{2}$ & $\mathrm{Fe}_{2} \mathrm{O}_{3}$ & $\mathrm{CaO}$ & $\mathrm{MgO}$ & $\mathrm{Na}_{2} \mathrm{O}$ & $\mathrm{K}_{2} \mathrm{O}$ & $\mathrm{P}_{2} \mathrm{O}_{5}$ \\
\hline Concentrate & 98.90 & 0.50 & 0.10 & 0.05 & 0.03 & 0.05 & 0.06 & $\mathrm{t}$ & $\mathrm{t}$ \\
\hline
\end{tabular}




\section{CONCLUSIONS}

The following conclusions may be drawn from beneficiation of silica sand deposits of Jabal Allouga, Um Bogma area at west central Sinai

(1) The untreated samples subjected to wet washing or attrition scrubbing (El-Farraka mill) and separation by decantation does not satisfy the requirements of glass manufacture.

(2) Any one of the subsequent improvement methods as shaking table concentrator, followed by magnetic separation does upgraded the sand to satisfy the requirements of the glass industry.

(3) The beneficiation tests applied on Jabal Allouga sand deposits using magnetic separation improved the grade of silica sands up to $98.90 \%$ and reduced the iron content to $0.05 \%$ resulting in a product suitable for the glass industry. According to the U. S. specifications (Norton 1957) they are suitable for manufacturing sheet and plate glass. According to the report of the ceramic industry magazine (1966) the silica sand used for making container (amber) must have $0.05-0.08$ iron oxides.

It may be possible to use such processing to upgrade and improve the silica sand deposits at a wider scale operation, after which a feasibility study can be done on that resource to enhance the mineral wealth of Egypt

\section{REFERENCES}

Abu-Shabana, M.,1998. Glass sands of Abu-Thora formation west-central Sinai: Lithostratigraphy, geochemistry, suitability, and reserve estimation (abstract). $5^{\text {th }}$ Conference on geology of Sinai for development. Saint Catherine, South Sinai.

Ceramic Industry Magazine (CIM),1966. Materials for ceramic processing, 87, 137-140.

Kora, M.,1984. The Paleozoic exposures of Um Bogma area, Sinai. Ph.D. Thesis, Mansoura Univ., $280 \mathrm{p}$.

Norton, F.H.,1957. Elements of Ceramics. Addision-Wesley Publishing Co. Inc. Reading, Massachusetts.

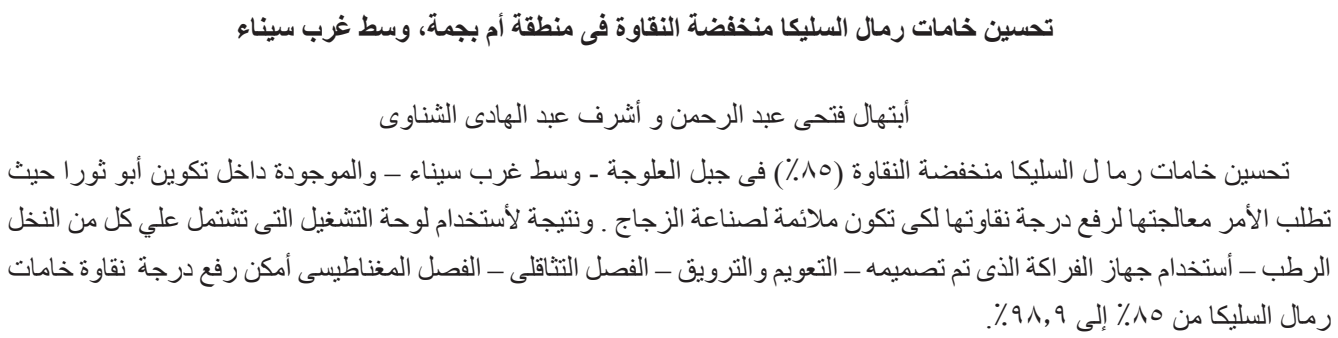

